\title{
Potassium in the syndrome of inappropriate antidiuretic hormone secretion
}

\author{
P. L. PADField \\ M.B., M.R.C.P.
}

\author{
J. J. MORTON \\ PH.D.
}

\section{Department of Medicine and Medical Research Council Blood Pressure Unit, Western Infirmary, Glasgow G11 6NT}

\begin{abstract}
Summary
Serum potassium concentration was normal $(\geqslant 3.6 \mathrm{mmol} / \mathrm{l})$ in 29 of 32 patients with the syndrome of inappropriate antidiuretic hormone excess (SIADH) associated with a bronchogenic carcinoma. In 11 of the patients there was no significant change in serum potassium concentration after correction of the syndrome, by fluid restriction. Hypokalaemia is thus an uncommon finding in SIADH due to bronchogenic carcinomas.
\end{abstract}

\section{Introduction}

Descriptions of the biochemical features of the syndrome of inappropriate antidiuretic hormone (SIADH) excess (Bartter and Schwartz, 1967) emphasize an abnormality of sodium and water homoeostasis. Changes in potassium balance are rarely mentioned although a reduced total exchangeable potassium $\left(\mathrm{K}_{\mathrm{e}}\right)$ was noted in the earliest reported cases (Schwartz et al., 1957) and has since been described together with hypokalaemia in a small number of cases (Jones et al., 1968; Barraclough, 1971). A more recent description of the biochemical features of SIADH (De Troyer and Demanet, 1976) recorded a high incidence of hypokalaemia. In the present authors' experience of over 30 cases of SIADH, hypokalaemia is an uncommon finding and in view of this discrepancy they present their results.

\section{Patient and methods}

Thirty-two patients (12 female) with SIADH associated with a bronchogenic carcinoma were studied. Serum sodium and potassium (automated flame photometry), urine and plasma osmolality (freezing point depression) and plasma ADH concentration (Morton, Padfield and Forsling, 1975) were measured after an overnight fast and during recumbency in all patients. In 11 patients repeat measurements were made, under identical conditions, after a period of fluid restriction designed to correct the biochemical abnormalities of SIADH (Bartter and Schwartz, 1967). Results are expressed as mean \pm s.e. mean and the significance of changes

Request for reprints to: The Secretary, MRC Blood Pressure Unit, Western Infirmary, Glasgow G11 6NT induced by fluid restriction assessed by Student's paired ' $t$ ' test.

Results

Patients were aged from 49-80 years $(58 \pm 2)$. All initially presented with a serum sodium of $<125 \mathrm{mmol} / \mathrm{l}$ although at the time of ADH measurement values ranged from $106-135 \mathrm{mmol} / \mathrm{l}(122 \pm)$. Plasma ADH varied widely $(6-643 \mathrm{pg} / \mathrm{ml})$ and the values overlapped the normal range $(2 \cdot 5-11 \mathrm{pg} / \mathrm{ml})$ when all states of hydration were considered. Plasma ADH was, however, inappropriately high for the concurrent plasma osmolality (251 \pm $3 \mathrm{mosmol} / \mathrm{kg}$, range 218-271) (Fig. 1). Urine osmolality ranged from $276-788 \mathrm{mosmol} / \mathrm{kg}$ (583 \pm 23). The mean serum potassium concentration for the group was $4 \cdot 4 \pm 0 \cdot 1 \mathrm{mmol} / 1(3 \cdot 1-5 \cdot 5)$ and was $\leqq 3.6 \mathrm{mmol} / \mathrm{l}$ in only 3 patients $(3.1,3.2$ and $3.5 \mathrm{mmol} / \mathrm{l}$ ). Patients with the lowest serum sodium concentrations were not those with the lowest serum potassium. Hyponatraemia was corrected in 11 patients by fluid restriction $(118 \pm 1.5$ to $137 \pm$ $0.9 \mathrm{mmol} / \mathrm{l})$ and although plasma ADH did increase $(86 \pm 27$ to $131 \pm 80 \mathrm{pg} / \mathrm{ml})$ there was no significant change in serum potassium concentration $(4.42 \pm$ 0.17 to $4.37 \pm 0.2 \mathrm{mmol} / \mathrm{l})$. An increase of $0.5 \mathrm{mmol} / \mathrm{l}$ was seen in only 3 patients.

\section{Discussion}

The acute administration of ADH has been shown to increase renal excretion of potassium in a variety of animal species (Heller and Stephenson, 1950; Kurtzman et al., 1975; Hiatt, Miller and Katayanagi, 1975; Barraclough, 1975) In normal man, ADH given acutely in large doses can produce a moderate increase in the rate of potassium excretion (Barraclough and Jones, 1970) but it does not alter potassium status in more prolonged studies (Stormont and Waterhouse, 1961).

SIADH represents a situation of chronic ADH excess in man, often associated with malignancy. The observations of a reduced $\mathrm{K}_{\mathrm{e}}$ (Schwartz et al., 1957; Jones et al., 1968; Barraclough, 1971) have not always been confirmed (Kaye, 1966; Nolph and Schrier, 1970) and in cachectic patients could conceivably reflect a loss of muscle mass. 
While serum potassium does not necessarily reflect overall potassium status, it is important to know whether or not hypokalaemia is likely to be present in SIADH. De Troyer and Demanet (1976) recently described 26 cases of SIADH (without ADH measurement) of varying aetiology and recorded a $62 \%$ incidence of hypokalaemia (Serum $\mathrm{K}^{+}$ $<3.6 \mathrm{mmol} / \mathrm{l})$. Among 32 patients, the present authors have seen hypokalaemia in only 3 cases $(9 \%)$ and have been unable to show consistent changes in serum potassium concentration during correction of the syndrome.

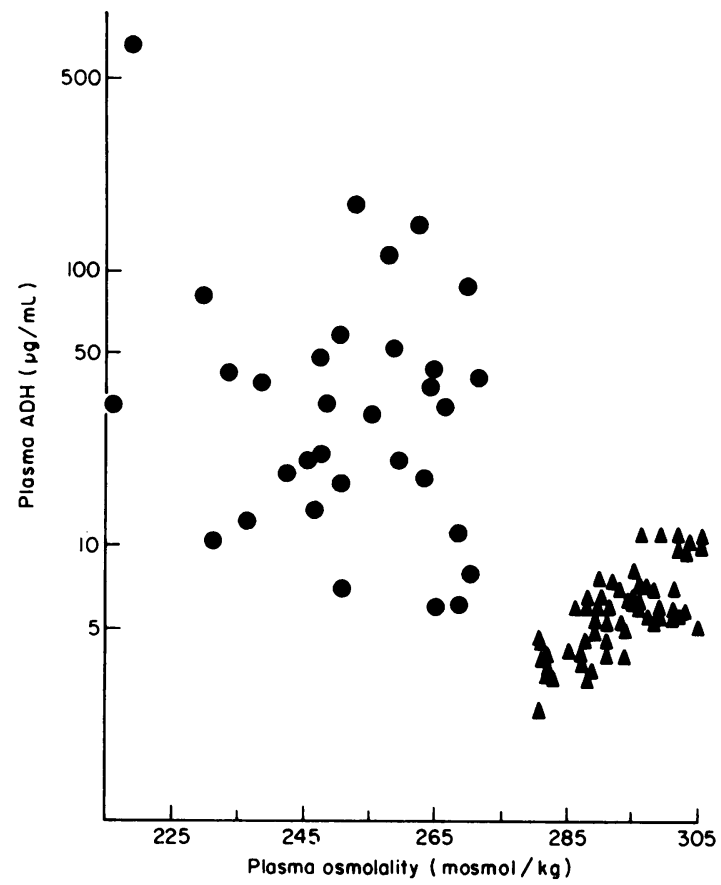

FIG. 1. Relationship of plasma ADH concentration to cuncurrent plasma osmolality in patients with the syndrome of inappropriate antidiuretic hormone (SIADH) release and in normal subjects. SIADH in carcinoma of the bronchus; $\Delta$, normal subjects (all states of hydration).

This striking difference in 2 series of comparable size may be accounted for by the different modes of presentation. None of the patients described was receiving any agents likely to affect serum potassium concentration. This was not the case in the series of DeTroyer and Demanet (1976). Of their 16 patients with hypokalaemia, 11 had either consumed 'vast quantities' of beer, received 'extensive' intravenous fluids (nature and potassium content not described) or had been given diuretics. It is known that diuretics may produce hypokalaemia and that 'vast quantities' of beer can provide a dilutional hyponatraemia together with profound hypokalaemia (Demanet et al., 1971;
Hilden and Svendsen, 1975). Although the mechanism of the hypokalaemia is ill understood, it is produced by the beer per se, without SIADH. It seems possible, therefore, that factors other than SIADH may have contributed to the hypokalaemia in many of the patients. On the basis of these results it is concluded that unprovoked hypokalaemia is an unusual finding in SIADH associated with bronchogenic carcinoma.

\section{References}

BARRAClOUGH, M.A. (1971) Inappropriate secretion of antidiuretic hormone and potassium depletion. Proceedings of the Royal Society of Medicine, 64, 1069.

BarRaClough, M.A. (1975) Potassium depletion induced by vasopressin and overhydration in the rabbit. Clinical Science and Molecular Medicine, 49, 535.

Barraclough, M.A. \& Jones, N.F. (1970) The effect of vasopressin on the resorption of sodium, potassium and urea by the renal tubules in man. Clinica! Science, 39, 517.

BartTer, F.C. \& SchwarTz, W.B. (1967) The syndrome of inappropriate antidiuretic hormone secretion. American Journal of Medicine, 42, 790.

Demanet, J.C., Bonnyns, M., Bleiberg, H. \& Stevens Rocmans, C. (1971) Coma due to water intoxication in beer drinkers. Lancet, ii, 1115.

DE Troyer, A. \& Demanet, J.C. (1976) Clinical, biological and pathogenic features of inappropriate secretion of antidiuretic hormone. Quarterly Journal of Medicine (NS) 45,521 .

Heller, H. \& Stephenson, R.P. (1950) Effect of posterio pituitary extract and its fractions on renal electrolyte excretion. Nature. London, 165, 189.

Hiatt, N., Miller, A. \& Katayanagi, A.T. (1975) Kaluresis and diuresis after administration of antidiuretic hormone to hyperkalemic dogs. American Journal of Physiology, 228, 1108.

Hilden, T. \& Svendsen, T.L. (1975) Electrolyte disturbances in beer drinkers. Lancet, ii, 245.

Jones, N.F., Barraclough, M.A., Zorsling, M.L. \& PETCH, C.P. (1968) Inappropriate production of vasopression, potassium deficiency and cerebrovascular disease. American Journal of Medicine, 45, 474.

KAYE, M. (1966) An investigation into the cause of hyponatremia in the syndrome of inappropriate secretion of antidiuretic hormone. American Journal of Medicine, 41, 910.

Kurtzman, N.A., Rogers, P.W., Boonjarern, A. \& ARRUDA, J.A.L. (1975) Effect of infusion of pharmacologic amounts of vasopressin on renal electrolyte excretion. American Journal of Physiology, 228, 890.

Morton, J.J., Padfield, P.L. \& Forsling, M.L. (1975) A radioimmunoassay for plasma arginine vasopressin in man and dog: Application to physiological and pathological states. Journal of Endocrinology, 65, 511.

NolPH, K.D. \& Schrier, R.W. (1970) Sodium potassium and water metabolism in the syndrome of inappropriate antidiuretic hormone secretion. American Journal of Medicine, 49, 534.

Schwartz, W.B., Bennett, W., Curelop, S. \& Bartter, F.C. (1957) A syndrome of renal sodium loss and hypernatremia probably resulting from inappropriate secretion of antidiuretic hormone. American Journal of Medicine, $23,529$.

Stormont, J.M. \& Waterhouse, C. (1961) The genesis of hyponatremia associated with marked overhydration and water intoxication. Circulation, 24, 191. 